\title{
PENDIDIKAN LITERASI PADA PEMBELAJARAN KITAB KUNING DI PONDOK PESANTREN SENTOT ALI BASYA JA'AL HAQ KOTA BENGKULU
}

\author{
Falahun Ni'am \\ (falahun@iainbengkulu.ac.id) \\ Muhammad Hidayaturrahman \\ (hidayat17.hr@gmail,com) \\ Nur Hidayat \\ (nur_hidayat@iainbengkulu.ac.id)
}

\begin{abstract}
Abstrak:
Pendidikan literasi merupakan hal yang perlu diperhatikan di dalam semua sektor pendidikan, karena dengan kemampuan literasi yang baik akan menumbuhkan sikap selektif dan hati-hati dalam menerima sebuah informasi. Pesantren merupakan salah satu lembaga pendidikan yang tertua di Indonesia yang menanamkan pendidikan literasi yang berpegang teguh pada kejelasan sanad keilmuan. Karakteristik pesantren tersebut membuat penulis ingin meneliti dan membahas tentang pendidikan literasi yang ada pada salah satu pondok pesantren di kota Bengkulu yaitu pondok pesantren Sentot Ali Basya Ja'al Haq. Dalam penelitian ini, penulis menggunakan metode penelitian berupa studi kasus, dengan teknik pengumpulan data berupa observasi, wawancara, dan dokumentasi. Pendidikan literasi pada pondok pesantren Sentot Ali Basya Ja'al Haq terlihat pada proses pembelajaran dengan menggunakan beberapa metode yang fokus pada literasi yang kuat, yang berupa: Maknani (Tarjamah Harfiyah), Sorogan, Bandongan/Wetonan, dan Musyawarah (diskusi).
\end{abstract}

Kata Kunci: Pendidikan Literasi, Pesantren, Sentot Ali Basya

\begin{abstract}
:
Literacy education is something that needs to be considered in all education sectors, because good literacy skills will foster a selective and careful attitude in receiving information. Pesantren is one of the oldest educational institutions in Indonesia that instills literacy education that adheres to the clarity of the scientific chain. The characteristics of the pesantren make the author want to research and discuss literacy education in one of the Islamic boarding schools in the city of Bengkulu, namely the Sentot Ali Basya Ja'al Haq Islamic Boarding School. In this paper, the author uses a research method in the form of a case study. Literacy education at the Sentot Ali Basya Ja'al Haq Islamic boarding school is seen in the learning process by using several methods that focus on strong literacy, these methods are: Maknani (Tarjamah Harfiyah), Sorogan, Bandongan/Wetonan, and Musyawarah (discussion).
\end{abstract}

Keywords: Literacy education, Pesantren, Sentot Ali Basya

\section{Pendahuluan}

Pendidikan literasi merupakan sesuatu yang sangat menarik dari beberapa istilah dalam pendidikan yang muncul akhir-akhir ini. Pendidikan Literasi telah digalakkan dalam berbagai sektor kehidupan. Pendidikan literasi tidak terbatas dalam kegiatan membaca dan menulis saja, tetapi terkait erat dengan gerakan bersama dalam memahami informasi dan ilmu pengetahuan secara komprehensif sehingga setiap orang bisa memiliki pemahaman analitis dan kritis yang baik. Literasi bersifat kompleks dan komprehensif karena men- jadi kemampuan dasar yang harus dimiliki oleh seseorang dalam konteks kehidupan. Oleh karena itu, pendidikan literasi dalam ruang keluarga, lembaga pendidikan, masyarakat, bangsa dan negara menjadi sesuatu yang penting dan wajib untuk ditumbuhkan dan dibudayakan.

Pendidikan literasi menjadi sangat penting karena dengan pendidikan literasi orang akan selektif terhadap informasi yang berimbas pada peningkatan kualitas sumber daya manusia. Literasi identik dengan Maharah al-lughah secara keseluruhan, yakni Maharah istima', kalam, qira'ah, 
dan kitabah. Seseorang bisa disebut literate, jika mampu menguasai keempat Maharah al-lughah tersebut secara sekaligus. Oleh sebab itu, kemampuan literasi wajib menjadi jantung dari seluruh proses pendidikan ${ }^{1}$. Dengan demikian, pendidikan literasi dapat diartikan sebagai pendidikan yang menerapkan keseluruhan keterampilan berbahasa dalam proses pembelajaran untuk mendapat hasil yang maksimal.

Pendidikan literasi dapat ditemukan penerapannya di hampir semua bidang pendidikan tanpa terkecuali pendidikan di pondok pesantren. Pendidikan di pondok pesantren yang sumber utama pembelajarannya adalah kitab kuning dengan tradisi literasinya yang sangat kental. $\mathrm{Hal}$ ini bisa dilihat dari posisi kemahiran dalam menguasai Maharah al-lughah yang begitu dijunjung tinggi di pondok pesantren karena sebagai fungsi dan kunci dalam kelancaran pembelajaran kitab kuning. Sebagai literatur yang bersifat universal klasik, untuk memahami isi kitab kuning sangat membutuhkan ilmu bahasa sebagai pengantar studi $^{2}$. Untuk itu penulis membahas tentang bagaimana pendidikan literasi pada pembelajaran kitab kuning di pondok pesantren Sentot Ali Basya Ja'al Haq kota Bengkulu.

\section{Tinjauan Pustaka}

\section{Pembelajaran Kitab Kuning}

Imam Bawani (1990) yang mengartikan kitab kuning sebagai kitab gundul. Disebut gundul sebab tidak terdapat syakal (tanda baca) seperti halnya Al Quran yang ada tanda baca seperti fathah, kasrah, dhammah dan sukun.

Imam Bawani juga mengemukakan bahwa kitab kuning disinyalir sebagai kitab warisan abad

${ }^{1}$ Umi Hanifah, "Pengembangan Literasi Berbicara Bahasa Arab (Maharat Al-Kalam) Di Madrasah Ibtidaiyah (MI)," Elementary: Islamic Teacher Journal 6, no. 2 (2018): 206-26, https://doi.org/http://dx.doi.org/10.21043/ elementary.v6i2.4383.

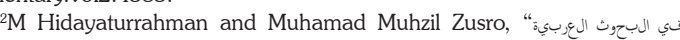

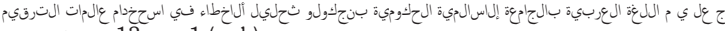
. 13 , no. 1 (n.d.). pertengahan Islam yang banyak dimanfaatkan oleh pesantren-pesantren sampai sekarang.

Menurut Martin Van Bruinessen Kitab kuning adalah kitab klasik yang telah ditulis dari beberapa abad yang lalu dengan bahasa Arab, juga sering dimanfaatkan sebagai pedoman pembelajaran di pesantren-pesantren ${ }^{3}$.

Azyumardi Azra (2002) mendefinisikan kitab kuning dengan pengistilahan kitab yang dulunya ditulis atau dicetak di atas kertas berwarna kekuning-kuningan ${ }^{4}$.

Isi kitab kuning mempunyai karakteristik unik dan berbeda yakni memiliki jaringan, genealogi, silsilah atau yang biasa disebut dengan istilah sanad. Kitab kuning tidak ditulis oleh orang yang sembarangan melainkan tokoh yang memiliki sanad yang jelas dan bersambung sampai sumber pokok yaitu Nabi Muhammad SAW 5 .

Amin Haedar mengkategorikan kitab kuning sebagai kitab-kitab berbahasa Arab tanpa tanda baca yang disebut juga dengan kitab gundul, untuk dapat membacanya santri harus menguasai ilmu alat yaitu ilmu Nahwu dan ilmu Sharaf ${ }^{6}$.

Istilah kitab kuning sebenarnya dipusatkan pada kitab-kitab warisan abad pertengahan Islam yang masih digunakan pesantren sampai sekarang. Menurut Azyumardi Azra sejarah masuknya kitab kuning ke Indonesia pada abad 17. Alah satu sebab masuknya kitab-kitab tersebut ke Indonesia adalah santri jawa yang membawanya ketika pulang ke tanah air setelah usai masa belajar di Haramain. Salah satu contohnya seperti kitab 'taqrib' karya Abu Syuja al-Isfahani (1196 M) atau ada juga 'al Muharrar' karya Abu Qoshim al-Rafi'I (1226 M) dan kitab-kitab lainnya.

Setidaknya di abad ke-17 ini pulalah, semakin banyak santri yang belajar ke tanah suci. Sepulang dari sana, lagi-lagi para santri membawa pu-

${ }^{3}$ Al Rasuidin, "Pembelajaran Kitab Kuning Di Pesantren Musthafawiyah, Mandailing Natal," Journal of Contemporary Islam and Muslim Societies 1, no. 1 (2017): 41-67, https://doi.org/10.30821/jcims.v1i1.324.

${ }^{4} \mathrm{ARr}$ Rasikh, "Pembelajaran Kitab Kuning Pada Pondok Pesantren Khusus Al-Halimy DESA Sesela Kabupaten Lombok Barat," Jurnal Penelitian Keislaman 14, no. 1 (2018): 71-84. 
lang kitab-kitab untuk dikaji dan ditransformasikan di tanah air. Tidak jarang dari mereka yang akhirnya menulis kitab yang merujuk pada kitabkitab yang sudah mereka pelajari. ${ }^{7}$

\section{Pendidikan Literasi di Pesantren}

Menurut beberapa ahli, sebagaimana yang dikutip oleh Zamakhsyari antara lain: Jhons, menyatakan bahwa kata santri berasal dari bahasa Tamil yang berarti guru mengaji. Sementara itu, CC. Berg berpendapat bahwa istilah ini berasal dari istilah shastri yang dalam bahasa India berarti orang yang tahu buku-buku suci agama Hindu, atau seorang sarjana ahli kitab suci agama Hindu. Kata shastri berasal dari kata shastra yang berarti buku-buku suci, buku-buku agama, atau bukubuku tentang ilmu pengetahuan.

Nurchalish Madjid pernah menegaskan, pesantren ialah artefak peradaban Indonesia yang dibangun sebagai institusi pendidikan keagamaan bercorak tradisional, unik dan indigenous. Mastuhu memberikan pengertian dari segi terminologis adalah sebuah lembaga pendidikan Islam tradisional yang mempelajari, memahami, menghayati dan mengamalkan ajaran Agama Islam dengan menekankan pentingnya moral keagamaan sebagai pedoman perilaku sehari-hari ${ }^{8}$.

Menurut PMA Nomor 13 Tahun 2014 tentang Pendidikan Keagamaan Islam, pasal 5 disebutkan bahwa "Pesantren wajib memiliki unsur-unsur pesantren yang salah satunya adalah pengajian atau kajian kitab kuning atau dirasah islamiyah dengan pola mu'allimin ${ }^{9}$.

Dalam waktu yang cukup lama, pembelajaran kitab-kitab Islam klasik mengiringi pendidikan pesantren secara umum. Kitab-kitab pembelajaan tersebut merupakan karangan-karangan

${ }^{5}$ Ahmad Helwani Syafi'i, "Pembelajaran Kitab Kuning Di Pondok Pesantren Khusus Al-Halimy Sesela," Ibtida'iy : Jurnal Prodi PGMI 5, no. 2 (2020): 40-49.

${ }^{6}$ Achmad Ridlowi, "Implementasi Dan Problematika Pembelajaran Kitab Kuning Dengan Arab Pegon ( Studi Di Ponpes Al-Falah Karangrejo Pacitan )," Jurnal Studi Agama Islam 11 (2018): 28-44.

${ }^{7}$ Faizal Bachrong, "Pembelajaran Kitab Kuning Di Pondok Pesantren Hidayatullah Ternate," INTAJ : Jurnal Penelitian Ilmiah 3, no. 1 (2019): 59-80, ulama yang menganut faham Syafi'i. Nurcholis majid mengemukakan bahwa yang menjadi konsentrasi keilmuwan di pondok pesantren meliputi cabang ilmu-ilmu 1) Fiqih misalnya safinah al-Najah, fath al-Qarib, Sulam al-Taufiq,fathul mu'in, fathul al- wahab 2) Ilmu tauhid misalnya Aqqidah al-awam, bada'ula amal dan sanusiah 3) Ilmu tasawuf misalnya Al-Irsyadu, al-Ibad, Tanbih al-Ghafilin, Ihya' Ulumuddin, alhikam 4) Ilmu nahu sharaf misal Matnu Aj-Jurumiyah, Nadzmu al-imriti, Alfiyah Ibn Malik, Awamil, Nadzmu alMaqsud $^{10}$.

Pesantren yang disebut sebagai subculture mempunyai tradisi tentang literasi yang sangat dijaga yaitu sanad keilmuan. Pesantren sangat memegang teguh adanya sanad yang harus bersambung karena, Lau la al-Isnad laqala man sya'a ma sya'a (jika tidak ada sanad persambungan keilmuan, maka setiap orang akan berpendapat semaunya sendiri). Hal ini menegaskan bahwa tradisi literasi dalam pondok pesantren sangat dijaga, baik secara kualitasnya maupun kuantitasnya ${ }^{11}$.

\section{Metode Penelitian}

Jenis penelitian menggunakan metode studi kasus. Studi kasus adalah kajian yang mendalam tentang sebuah waqi'iyyah, bi'ah, dan haliyah tertentu yang dapat menyingkap atau memahami sesuatu hal ${ }^{12}$. Dalam penelitian ini, sesuatu yang dikaji secara mendalam adalah waqi' iyyah, bi'ah, dan haliyah dalam proses pembelajaran kitab kuning. Studi kasus merupakan jenis penelitian yang masuk dalam kelompok penelitian deskriptif. Studi kasus digunakan ketika peneliti menjawab pertanyaan deskriptif atau pertanyaan penjelasan. Pertanyaan deskriptif yang dijawab

\footnotetext{
https://doi.org/10.35897/intaj.v3i1.184.

${ }^{8}$ Taslim Syahlan et al., "Pendampingan Santri Untuk Membangun Tradisi Literasi Di Pondok Pesantren Al-Mubarok Mranggen Demak," Dimas 19 (2019): 49-60.

${ }^{9}$ Fatimah Azzahra Mutmainah, "Pemikiran a. Chaedar Alwasilah Tentang Pendekatan Literasi (Genre-Based Approach) Dan Pembelajaran Bahasa Arab," Jurnal Al Bayan: Jurnal Jurusan Pendidikan Bahasa Arab 10,
} 
adalah pendidikan literasi. Pelaksanaan penelitian bertempat di salah satu unit pada Pesantren Sentot Ali Basya Ja'al Haq Kota Bengkulu. Datadata dikumpulkan dengan wawancara, observasi, dan dokumentasi. Data-data yang dibutuhkan dalam penelitian ini adalah informasi tentang keseluruhan proses pembelajaran kitab kuning, dan hal-hal yang mendukung proses pembelajaran. Ada enam sumber data yang bisa menjadi fokus pengumpulan data dalam penelitian studi kasus, yakni observasi langsung, wawancara, dokumen, rekaman arsip, observasi pemeran, serta perangkat fisik ${ }^{13}$.

\section{Hasil dan Pembahasan}

Pembelajaran Kitab Kuning pada Madrasah Takhasusiyah Diniyah (MTD) Sentot Ali Basya Sentot Ali Basya Ja'al Haq masuk di dalamnya adalah metode yang digunakan, guru sebagai pengajar, media yang digunakan, dan jadwal pembelajaran.

\section{a. Metode pembelajaran}

Metode pembelajaran merupakan cara yang digunakan oleh guru untuk menyampaikan materi kepada peserta didik dalam kegiatan belajar mengajar. Secara umum, pesantren memiliki beberapa macam metode yang digunakan dalam kegiatan pembelajaran kitab kuning ${ }^{14}$.

Berikut ini metode yang digunakan dalam kegiatan pembelajaran kitab kuning di MTD Sentot Ali Basya Ja'al Haq :

1. Maknani (Tarjamah Harfiyah) Metode maknani adalah guru membacakan teks kitab kuning dan mengartikannya kata demi kata, kemudian menjelaskan maksud teks tersebut, sedangkan santri menulis arti teks tersebut pada kitab kuning masing-masing sebagaimana guru memaknai teks kitab kuning tersebut. Santri

no. 01 (2018), https://doi.org/10.24042/albayan.v10i01.2599.

${ }^{10}$ Syahlan et al., "Pendampingan Santri Untuk Membangun Tradisi Literasi Di Pondok Pesantren Al-Mubarok Mranggen Demak."

${ }^{11}$ Lailatul Fitriyah, Marlina Marlina, and Suryani Suryani, "Pendidikan Literasi Pada Pembelajaran Kitab Kuning Di Pondok Pesantren Nurul Huda Sukaraja," Titian Ilmu: Jurnal Ilmiah Multi Sciences 11, no. 1 (2019): 20-30, https://doi.org/10.30599/jti.v11i1.351. mendengarkan penjelasan guru, dan mencatat penjelasan-penjelasan penting yang disampaikan oleh guru. Metode pembelajaran seperti ini dilakukan dalam pembelajaran klasikal pada pelajaran-pelajaran Nahwu, Shorf, Tauhid, Fiqih, Tafsir, Hadits, dan Akhlak. Dalam pelaksanaan metode ini, santri menggunakan kode mengenai kedudukan kata untuk memahami kata demi kata dalam struktur dalam sebuah kalimat. Misalnya kode Fa ( ف ) sebagai kode

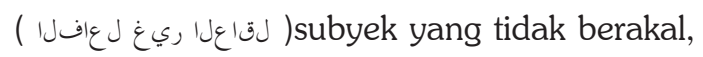

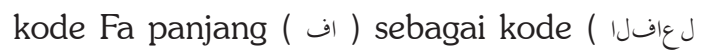
(لقاعل subyek yang berakal. Guna memudahkan santri dalam menghafal kode-kode tersebut, guru menyiapkan materi khusus berupa lembaran yang bernama Kaifiyatul Ma'ani bi allkhtishor. Selain itu, untuk membantu santri agar mudah dalam memahami tata bahasa Arab, guru menyiapkan lembaran yang berisi ringkasan materi tata bahasa Arab dari segi sintaksis dan morfologi berupa Jadwal anNahwi al-Awwal, ats-Tsani, dan ats-Tsalits dan berupa Jadwal ash-Shorfi al-Awwal, ats-Tsani, dan ats-Tsalits.

2. Sorogan Pembelajaran kitab kuning

Tata cara pelaksanaan metode ini adalah dengan menunjuk santri secara bergantian untuk membacakan kembali teks yang telah dibaca oleh guru beserta tarkib dan shorfnya (kedudukan/ perubahan kata dalam kalimat) kemudian menjelaskan maksud teks. Pelaksanaan metode ini biasanya pada awal atau akhir pembelajaran. Pelaksanaan pada awal pembelajaran bertujuan untuk mereview materi yang telah disampaikan pada pembelajaran sebelumnya. Pelaksanaan pada akhir

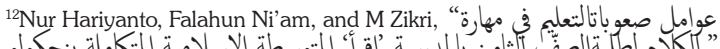

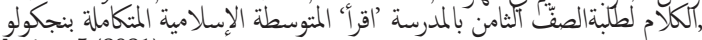
Imtiyaz 5 (2021).

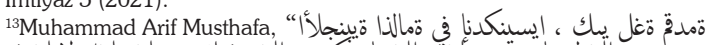

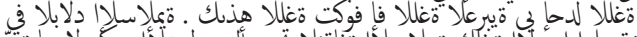

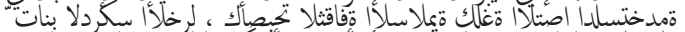

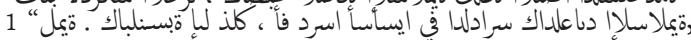
no. 1 (n.d.)

${ }^{14}$ Syahlan et al., "Pendampingan Santri Untuk Membangun Tradisi Literasi Di Pondok Pesantren Al-Mubarok Mranggen Demak."
} 
pembelajaran bertujuan untuk melihat seberapa baik penyerapan santri terhadap materi pelajaran yang tengah disampaikan guru. Metode ini dilaksanakan pada pembelajaran untuk pelajaran-pelajaran seperti pada metode Maknani. Santri akan mempresentasikan materi yang telah diterima setelah ditunjuk oleh guru secara acak. Masing-masing dari santri secara mandiri memahami teks yang telah dipilihkan oleh guru, kemudian terjadi dialog antara guru dan santri yang biasanya dimulai dari koreksi guru terhadap bacaan santri yang kurang tepat. Selain mengoreksi bacaan murid, guru juga akan menguji pemahaman santri dengan cara meminta santri menjelaskan maksud dari teks yang telah dibaca. Pembacaan santri terhadap teks meliputi membaca dengan menerapkan gramatika dan membaca dengan memaknai teks dan menjelaskan maksudnya. Pada pembelajaran dengan metode ini, santri tidak hanya dituntut benar-benar tuntas menguasai teknik pembacaan tetapi juga benarbenar tuntas menguasai materi pembahasan. Ustadz Azis yang merupakan salah satu ustadz yang mengajar di pesantren Ja'al Haq mengatakan bahwa metode ini tidak hanya membuat santri mampu membaca teks kitab kuning yang serba Arab, tetapi juga memungkinkan baginya untuk kitab-kitab lain yang secara tematik memiliki pembahasan yang sama dengan teks yang dibaca. ${ }^{16}$

\section{Bandongan/Wetonan}

Metode ini dilaksanakan dengan cara kiai membacakan teks kitab kuning dan membacakan artinya di hadapan semua santri dari semua kelas (semacam studium generale). Sementara itu, santri menuliskan arti kata perkata sebagaimana arti yang disampaikan oleh kiai. Dalam metode ini, tidak jarang guru menjelaskan

${ }^{5}$ Hasil Observasi, pada tanggal 18 Mei 2021 di Pondok Pesantren Ja'al

${ }^{16}$ Hasil wawancara dengan ustadz Azis, pada tanggal 19 Mei 2021 di Pondok Pesantren Ja'al Haq
}

maksud dari teks yang dibaca secara panjang lebar, termasuk juga kiai menjelaskan aspek tata bahasa (tarkib) dari teks yang dibaca. Dalam metode ini, tidak jarang kiai memasukkan cerita-cerita yang sifatnya memotivasi santri atau cerita-cerita teladan yang bersumber dari kisah-kisah Rosul, Shohabat, kisah-kisah teladan, atau bahkan kisah kiai sendiri.

4. Musyawarah (diskusi)

Pada kegiatan ini, santri (siswa) menunjuk ketua kelompok sebagai pemimpin diskusi. Jika musyawarah ini dalam tingkatan kelas, maka musyawarah dimaksudkan untuk mendiskusikan materi pelajaran yang sudah dipelajari. Pada kegiatan pembelajaran ini, santri dilatih untuk mempunyai argumentasi yang kuat dengan merujuk pada kitab-kitab yang telah dipelajari atau kitab-kitab lain yang memungkinkan bagi mereka untuk membacanya. Metode pembelajaran kitab kuning yang seperti ini melatih seluruh keterampilan berbahasa santri; mulai dari istima', kalam, qira'ah, dan kitabah. Latihan menyimak terjadi ketika santri mendengarkan apa yang disampaikan oleh teman diskusi yang lain. Latihan berbicara terjadi ketika santri menyampaikan argumentasinya. Latihan membaca terjadi ketika santri membaca dan menelaah teks-teks yang menjadi rujukan dalam pembahasan masalah. Guru yang menjadi tenaga pengajar di MTD Sentot Ali Basya Ja'al Haq sejumlah 15 guru. Dari 15 guru tersebut, tujuh di antaranya adalah alumni pondok pesantren al-Anwar Srang Rembang Jawa Tengah, pondok pesantren Lirboyo Jawa Timur, pondok pesantren Maslakul Huda Kajen, Pati Jawa Tengah, dan pondok pesantren Mamba'ul Ulum Pakis, Pati Jawa Tengah. Ini menjadi jaminan bahwa guru-guru yang ada pada MTD Sentot Ali Basya Ja'al Haq memiliki kompetensi kebahasaan (bahasa Arab) yang baik. Selain itu, adalah jaminan bahwa mereka memiliki pemahaman yang baik terhadap teks kitab kuning yang dipelajari dan 
tentunya memiliki sanad keilmuan yang jelas. Keterampilan berbahasa Arab ini berkaitan dengan keterampilan istima', kalam, qira'ah, dan kitabah. Kompetensi kebahasaan ini yang memang diperlukan dalam pembelajaran kitab kuning.

Jadwal pembelajaran kitab kuning di MTD Sentot Ali Basya Ja'al Haq meliputi jadwal sekolah diniyah formal, dan jadwal kegiatan harian. Jadwal sekolah formal dilaksanakan pada pagi dan sore hari. Jadwal pagi dimulai pada pukul 07.45 WIB hingga pukul 10.15 WIB. jadwal sekolah sore dimulai pada pukul 14.30 WIB hingga pukul 16.20 WIB. Jadwal pembelajaran sekolah diniyah formal meliputi materi-materi pokok pada kurikulum diniyah formal. Sementara jadwal harian memuat kegiatan harian yang dilaksanakan oleh santri. Termasuk dalam jadwal harian adalah jadwal pembelajaran kitab kuning di luar jadwal sekolah diniyah formal yang sifatnya penguatan terhadap pemahaman materi pada sekolah diniyah formal (pembelajaran tambahan). Pembelajaran tambahan yang juga dijadwalkan dilaksanakan pada jam istirahat antara jadwal diniyah pagi dan sore, kegiatan pembelajaran malam hari, dan kegiatan pembelajaran pagi hari setelah subuh. Pembelajaran pada jam istirahat memuat pembelajaran bahasa Arab dan pembacaan teks kitab kuning dengan menggunakan metode modeling. Salah satu santri yang dianggap cakap ditunjuk untuk membaca teks kitab kuning di hadapan santri-santri yang lain, sedangkan guru mendengarkan dan mengoreksi bacaan santri. Kegiatan pembelajaran pada malam hari dilaksanakan untuk menguatkan pemahaman santri terhadap teks kitab kuning. Kegiatan pembelajaran pada malam hari meliputi pengajian kitab kuning secara bandongan oleh kyai, sorogan kitab kuning, dan diskusi berkaitan dengan materi kitab kuning. Sementara itu, kegiatan pembelajaran pada pagi setelah subuh lebih pada hafalan terhadap nadhom (bait puisi) yang berkaitan dengan materi dalam pembelajaran kitab kuning. Secara keseluruhan proses pembelajaran kitab kuning di MTD Sentot Ali Basya Ja'al Haq memiliki jadwal dan waktu yang memadai. Santri mulai dari bangun tidur hingga tidur kembali berhadapan dengan teks kitab kuning, baik dalam bentuk prosa (natsr) maupun dalam bentuk puisi/syair (nadhom). Pendidikan literasi pada pembelajaran kitab kuning di MTD Sentot Ali Basya Ja'al Haq sebagaimana penjelasan di atas telah memenuhi persyaratan untuk dapat dikatakan bahwa pembelajaran kitab kuning pada MTD Sentot Ali Basya Ja'al Haq telah menjadikan literasi sebagai jantung dalam proses pendidikan.

\section{Kesimpulan}

Pendidikan Literasi dalam pembelajaran kitab kuning di (MTD) Sentot Ali Basya Sentot Ali Basya Ja'al Haq berupa penggunaan metode:

1. Maknani (Tarjamah Harfiyah)

2. Sorogan Pembelajaran kitab kuning

3. Bandongan/Wetonan

4. Musyawarah (diskusi)

Dalam pembelajaran tersebut juga menggunakan strategi pembelajaran yang mengajarkan tentang Literasi.

\section{Daftar Pustaka}

Faizal Bachrong. "Pembelajaran Kitab Kuning Di Pondok Pesantren Hidayatullah Ternate." INTAJ : Jurnal Penelitian Ilmiah 3, no. 1 (2019): 59-80. https://doi.org/10.35897/intaj.v3i1.184.

Fitriyah, Lailatul, Marlina Marlina, and Suryani Suryani. "Pendidikan Literasi Pada Pembelajaran Kitab Kuning Di Pondok Pesantren Nurul Huda Sukaraja." Titian Ilmu: Jurnal Ilmiah Multi Sciences 11, no. 1 (2019): 20-30. https://doi.org/10.30599/jti.v11i1.351.

Hanifah, Umi. "Pengembangan Literasi Berbicara Bahasa Arab (Maharat Al-Kalam) Di Madrasah Ibtidaiyah (MI)." Elementary: Islamic Teacher Journal 6, no. 2 (2018): 206-26. 
Teacher Journal 6, no. 2 (2018): 206-26. https://doi.org/http://dx.doi.org/10.21043/elementary.v6i2.4383.

Hariyanto, Nur, Falahun Ni'am, and M Zikri. " عوامل صعوباتالتعليم في مهارة الكلام لطلبةالصنّ الثامن بالمدرسة 'اقرأ' المتوسطة الإسلامية المنكامة بنجكولو. "Imtiyaz 5 (2021).

Hidayaturrahman, M, and Muhamad Muhzil Zusro. "ميرعلا ثوحبلا يف ميقرتلا تاملاع مادخحسا يف واطخالأ ليلحث ولوكجنب

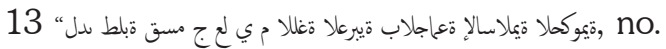
1 (n.d.).

Musthafa, Muhammad Arif. "مدقة ةغل يكك ، ايسينكدنا في ةمالنال

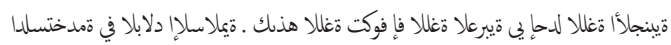

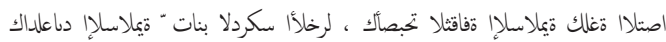

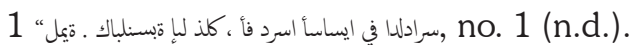

Mutmainah, Fatimah Azzahra. "Pemikiran a. Chaedar Alwasilah Tentang Pendekatan Literasi (Genre-Based Approach) Dan Pembelajaran Bahasa Arab." Jurnal Al Bayan: Jurnal Jurusan Pendidikan Bahasa Arab 10, no. 01 (2018). https://doi.org/ 10.24042/ albayan. v10i01. 2599.

Rasikh, ARr. "Pembelajaran Kitab Kuning Pada Pondok Pesantren Khusus Al-Halimy DESA
Sesela Kabupaten Lombok Barat." Jurnal Penelitian Keislaman 14, no. 1 (2018): 7184.

Rasyidin, Al. "Pembelajaran Kitab Kuning Di Pesantren Musthafawiyah, Mandailing Natal." Journal of Contemporary Islam and Muslim Societies 1, no. 1 (2017): 41-67. https://doi. org/10.30821/jcims.v1i1.324.

Ridlowi, Achmad. "Implementasi Dan Problematika Pembelajaran Kitab Kuning Dengan Arab Pegon ( Studi Di Ponpes Al-Falah Karangrejo Pacitan )." Jurnal Studi Agama Islam 11 (2018): 28-44.

Syafi'i, Ahmad Helwani. "Pembelajaran Kitab Kuning Di Pondok Pesantren Khusus AlHalimy Sesela." Ibtida'iy : Jurnal Prodi PGMI 5, no. 2 (2020): 40-49.

Syahlan, Taslim, Ali Imran, Laila Ngindana Zulfa, and as Shobirin Ma. "Pendampingan Santri Untuk Membangun Tradisi Literasi Di Pondok Pesantren Al-Mubarok Mranggen Demak." Dimas 19 (2019): 49-60. 